\title{
Dewey and Chinese Education: A Centennial Reflection
}

\author{
ZHANG Huajun \\ Faculty of Education, Beijing Normal University, Beijing, China \\ zhanghj@bnu.edu.cn
}

The year 2019 marks the 10oth anniversary of Dewey's two-year stay in China from 1919 to 1921. It is my honor to serve as the guest editor of this special issue on "Dewey and Chinese Education: A Centennial Reflection," supported by Professor Michael A. Peters and Professor Zhu Xudong, the editors-in-chief of Beijing International Review of Education. It has been a few years since my book titled John Dewey, Liang Shuming and China's Education Reform: Cultivate Individuality (Zhang, 2013) was published. Since that time, I have witnessed a steady spate of publications relating to Deweyan studies on China, written by both Chinese and international scholars in the fields of education and other disciplines, primarily philosophy. However, in light of a consideration of the turbulent history of such scholarship in China over the last 100 years, the recent burgeoning of Deweyan studies in China and on China should not be taken for granted. Instead, it should be viewed in the context of China's developmental trajectory that has entailed highly complex social and political conditions.

The contributors to this special issue engage with Dewey's writings from the following key perspectives. The first entails the recognition that Dewey's writings should be read from a comparative and cultural perspective to address practical problems in the field of Chinese education. Specifically, Dewey's emphasis on the intellectual, ethical, and aesthetic experiences of the individual resonates with the concept of self-cultivation in traditional Confucianism. The commonalities between these two schools of thought are also indicative of a possible vision for a new humanism in the contemporary world, where clashes and violence are prevalent. Second, we hold that to illuminate Dewey's legacy for Chinese education in the global context, it is necessary to consider his philosophy as a whole as opposed to extracting the part focusing on education from the wider body of his pragmatic thought. This exercise requires in-depth dialogue among scholars from different disciplines as well as from different 
societies, which is the primary objective of this special issue. Third, we aim to assess the historical value of Dewey's visit of China and to examine how and to what extent his legacy holds lessons for contemporary development in China.

\section{A Comparative and Cultural Perspective on Dewey's Philosophy}

In recent decades, there has been a resurgence of interest in Dewey's philosophy in the West that began with Richard Rorty. Following Rorty (1980), an increasing number of intellectuals have acknowledged the problems associated with liberal individualism and the crisis of individual-centered democracy (e.g., Rockefeller, 1991). Many western scholars have proposed a new direction for democracy and have sought to acquire intellectual resources from other schools of thought, especially Confucianism (e.g., Nevillie, 1985; Ames \& Hall, 1999; Grange, 2004). In general, these scholars have suggested that the cultivation of relational being holds promise for strengthening democracy. Thus, the legacy of Confucianism, which highlights the harmony of a communitarian living and considers self-cultivation as the key of education, is appealing.

In this special issue, we adopt a comparative perspective to explore the value of dialogues fostered between Deweyan pragmatism and other oriental schools of thought that include not only Confucianism but also Buddhism. Jim Garrison's article, "Mahayana Buddhism and Deweyan Philosophy" identifies several dimensions of congruence between Mahayana Buddhism and Deweyan pragmatism, including the nature of knowledge, the nature of humans, and the relationship between life and the environment. This perspective was rarely discussed in Deweyan scholarship. It indicates a potential possibility of more dialogues between Deweyan philosophy and Chinese traditional thoughts, as Buddhism as obviously an influential one. Len Waks' article titled "Democratic Self-Cultivation" draws on Confucian self-cultivation education, with the aim of enhancing Dewey's democratic education project, raising up interesting but controversial issues, such as classical study and ritual practice in contemporary western schools. In the section of "Short Essay" in this issue, Roger Ames and David Hansen (Western scholars) and Chen Yajun (a Chinese scholar), each discuss the value of cultural dialogue between Dewey and Chinese traditional thought.

In this issue, I would like to point out two different concepts: Dewey's philosophy and education and Dewey's philosophy of education. In chapter 24 of his 
classical work, Democracy and Education: An Introduction to Philosophy of Education (1916/1944), titled "Philosophy of Education," Dewey claimed that "if we are willing to conceive education as the process of forming fundamental dispositions, intellectual and emotional, toward nature and fellow men, philosophy may even be defined as the general theory of education" (p. 328). Dewey's readers are likely to be familiar with this widely cited statement. Here, I would like to elaborate further on this claim to bring out its specificity. When our concern is with the fundamental issue of education, we adopt a philosophical approach entailing studies on education. However, it was not Dewey's intention to construct a field of philosophy of education as a sub-discipline of philosophy, as reflected in his statement that philosophy itself "may even be defined as the general theory of education", as indicated above. Therefore, rather than extracting some of Dewey's ideas on education from his philosophy, we propose adopting a more comprehensive perspective, entailing an exploration of Dewey's philosophy as a whole set of thoughts.

In this issue, we have a scholar of philosophy, Wang Chengbing, contributed his article to this point. In his article titled "Education and the Reconstruction of Democratic Society: Two Main Themes in Dewey's Philosophy of Education," Wang considers "the growth of the individual" as the key for understanding Dewey's philosophy of democracy. Here, he used his subtitle of "Dewey's philosophy of education" same as Dewey's use of the subtitle in Democracy and Education. The articles in this issue by Jim Garrison, Len Waks, Roger Ames, and David Hansen all reflect this perspective of considering Dewey's philosophy as whole.

What then are the implications of this understanding of Dewey's philosophy for Chinese education? It is apparent that to draw insights from Dewey's thought requires an understanding of his naturalist pragmatism, viewed as a comprehensive philosophy that developed throughout his life, reaching maturity in his later works. It is not necessary to consider Dewey's philosophy as a prescription for reforming Chinese education in the context of the contemporary globalized world. However, a pragmatic stance that emphasizes relations and transactions with the social environment can be adopted to develop an understanding of the problems of Chinese education within the complex historical, political, social, and cultural contexts that have given rise to them. Therefore, the focus of our efforts should be on understanding the historical and cultural traditions as well as the social contexts of different theories and not on borrowing educational theories from the West. However, a deep grasp of Chinese historical and cultural traditions and their revitalization is required along with the development of educational theories that respond to problems that exist in a particular social context. In this issue, Zhao Kang's article "Why Did Hu Shi Introduce Dewey's Pragmatism to China as Only a Method?" 
discusses how Dewey's Chinese disciple Hu Shi transformed Dewey's thoughts in Chinese context during the May Fourth Movement period. Yang Zhixiang's article titled "New Confucian Liang Shuming's Transformation of John Dewey's Philosophy in Chinese Rural Education" describes the efforts of Liang Shuming, a modern Confucian and a contemporary of Dewey, towards this objective during a particular historical episode in China. The short essays by Zhang Binxian, Chen Yajun, and Chu Zhaohui are also reflective of this approach.

The Historical Value of Deweyan Scholarship on China and Chinese Education

Dewey's thought was enthusiastically explored by intellectuals and youth during the period of the May Fourth Movement, mainly in the latter part of the 1910 s and in the early 1920s. Many of Dewey's works were translated into Chinese then and his pragmatic philosophy was seriously considered as a potential approach for promoting China's social development but was soon replaced by Marxism. Later, during the period of 1949-1976, Dewey's philosophy was completely rejected in mainland China as he was perceived as a capitalist enemy. However, after China initiated the open-and-reform policy after 1978, he was once again acclaimed and recognized as an important western thinker. Dewey's philosophy acquired renewed value among scholars from different disciplines and was re-introduced to Chinese audiences. It is conceivable that scholars and students in the field of education may be the most appreciative of Dewey's readership.

In this issue, Liu Xing takes a particular historical episode in this centennial account of Dewey and Chinese education during Dewey's visit of China from 1919 to 1921. He uses archival sources available at Beijing Normal University to examine Dewey's role in the construction of China's first department of education. The title of his article is "A Seed Found its Ground: John Dewey in the Construction of the Department of Education at Beijing Normal University". Finally, Su Zhixin's article titled "John Dewey and Chinese Education: Comparative Perspectives and Contemporary Interpretations" makes a comprehensive conclusion for this special issue. She provides a historical literature review of Chinese education over the past century that addresses this concern on the historical value of Deweyan scholarship. Particularly, she highlights the prosperity of Deweyan study in the scholarship of Chinese education in the recent decade. In the section of "Short Essay", the Chinese education scholars Shan Zhonghui, Guo Faqi, and Chu Zhaohui also examine Deweyan studies in Chinese education from a historical perspective. 
Readers of this special issue may notice that some of the short essays are in both Chinese and in English. We invited a number of senior Chinese scholars to write short essays in Chinese. This is because we consider this journal to be a platform for fostering academic and cultural dialogues between Chinese and international scholars. Accordingly, we created a section of "Short Essay" for scholars to express their ideas in a relatively free style without being constrained by language issues. For the essays of Chinese scholars, we provide the original Chinese version as well as the translated English version.

Readers may also notice that there are many Chinese names and references in this issue. We adopted the pinyin (拼音) romanization system to denote Chinese names. However, because the pinyin system was adopted after 1958 in the mainland China, Chinese names used before that time, or those used outside of the mainland, were based on the earlier Wade-Giles romanization system. For example, $\mathrm{Hu}$ Shi is the spelling based on the pinyin system, whereas $\mathrm{Hu}$ Shih is the spelling based on the Wade-Giles system. In some articles, we have retained the spelling based on the older system used in some of the references while also providing the pinyin romanization and the Chinese characters, for example, Hu Shih (Hu Shi, 胡适) to enhance readability. Another source of confusion relating to Chinese names concerns the order of the appearance of the family and first names. Articles written in English generally follow a convention in which the first name appears before the family name. However, for the Chinese names appeared in this issue, we have applied the Chinese convention in which the family name appears first, followed by the first name, for example, Tao Xingzhi (陶行知), to respect the traditional style and integrity of the names.

\section{Acknowledgements}

Finally, I would like to take this opportunity to thank all of the contributors to this issue, namely the authors, reviewers, language editors and all of the individuals involved in this effort. I extend special thanks to Professor Michael Peters. Without his strong support and professional guidance, this issue would not have taken shape.

\section{References}

Ames, Roger \& Hal, David. (1999) The Democracy of the Dead: Dewey, Confucius, and the Hope for Democracy in China. Open Court. 
Dewey, John. (1916/1944) Democracy and Education. New York: The Free Press.

Grange, Joseph. (2004) John Dewey, Confucius, and Global Philosophy. Albany: SUnY Press.

Nevillie, Robert C. (1985) Wang Yangming and John Dewey on the Ontological Question. Journal of Chinese Philosophy. 12, 283-295.

Rorty, Richard (1980) Philosophy and the Mirror of Nature. Oxford: Oxford University Press.

Rockefeller, Steven (1991).John Dewey: Religious Faith and Democratic Humanism. New York: Columbia University Press.

Zhang, Huajun (2013) John Dewey, Liang Shuming and China's Education Reform: Cultivating Individuality. Lanham, MD: Lexington Books. 